\title{
Impact of Television Advertisements on Indian value system: A Prospective and Retrospective Approach
}

\author{
Shubha A \\ Research Scholar \\ REVA University \\ Dr. Narayana Reddy $\mathrm{P}$ \\ REVA University
}

\begin{abstract}
Everyday innumerable advertisements flash on our television screens and it is accused that these advertisements have negative impact on our value system. It is argues that these advertisements are violating our ethical norms, disrespecting culture and degrading women as the weaker sex, leading to sexual Pre-occupation and boosting materialism.
\end{abstract}

Keywords: advertisement, value system, Ethical norms and materialism.

\section{INTRODUCTION}

Advertising is something more than a sales message that occupies the space in and around new stories, magazine features and television programs. It's a complex form of communication that operates with objectives and strategies leading to various types of impact on consumer thoughts, feelings and actions.

Advertising is about creating a message and sending it to someone, hoping they will react in a certain way. Advertising becomes controversial when questions arise about hoe it influences people and whether that is a good thing, some say they hate it and that it makes them do things they really did not want to do, some see it as a fashion guide or as entertainment with good jokes, great music and fascinating images.

Advertising has evolved as society has changed. It has had an effect on society and at the same time society it also influencing advertising.

\section{HISTORY OF TELEVISION}

The word television is derived from ancient greek, "tel' meaning "far" and "vision" meaning "sight". In 1800's Paul Nipkow developed the first mechanical model of a television. In 1927 Philo Farnsworth invented the first working electronic television. The first electronic colour television was created in 1953 and first broadcast of television pictures began in Germany in 1935. In India today's television world has been divided into three domains.

a) Television Broadcasting.

b) Cable services.

c) Satellite services.

\section{Television advertising:}

Television advertising is embedded in television programming, so most of the attention in media buying, as well as in the measurement of advertising's effectiveness is focused on the performances of various shows and how they engage their audiences. Some programs are media stars and reach huge audiences, other reach small but selected audiences.

Television advertising has become the primary medium for moulding the public opinion. Over last few decades it has become incredibly persuasive, powerful and demanded mode of marketing and serving as a hottest platform to sell the products globally as well as locally. 
It also plays an important role in disseminating culture, informations and values due to its accessibility and availability and has brought the world closer together.

\section{LITERATURE REVIEW}

During a study of relevant literature one comes across a number of studies which deal with the extent of value degeneration promoted by Television advertising. A review of some of the major studies carried out across different countries during different periods on the same has been done.

Pollary, 1986: On the basis of reviewed literature it has been found that advertisements are generally criticized for targeting youth. Excessive use of sex appeals in the ads has led youth to involve in sexual pre-occupation, leading to undermining the strong Indian values.

Chatterji, 2005: Researchers have opened even though we talk about equal status being given to women in our society, still stereotypical portrayal of women in television ads has been criticized by viewers.

Roy, 2006: Women critics and feminists for a long time now have been voicing their opinion and fighting against the way women are portrayed in ads.

Richins, 1991: Examined the impact television on the psychology of the viewer. The study found that the ads which target young women lead them to compare their own attractiveness with the idealized images in the ads, resulting in dissatisfaction of self.

Fay and Price, 1994: A study with almost similar findings was conducted and found that slimming, dieting and body control advertisements directs at young women made them to compare their bodies with media images.

Richins, 1995: Studies holds the contention that promotes materialism and consumerism in society. It was pointed that exposure to advertisements enhances materialistic desires of the viewers.

Nuta, 2009: Studies indicated that In order to buy the advertised products, people are ready to take loans beyond their repayment capacity are even ready to commit crimes and resort to corruption.

As we can see, past research has claimed that advertising is harmful for the society and negatively influences its viewers. The present study is an attempt to test the validity of this claim.

\section{NEED OF THE STUDY}

The direction in which television ads are aired today leads to finding out appropriate solutions causing diminishing value system amongst youth. Complaints and concerns about television ads have been extensive since their advent. It is not only damaging society, but morality too.

Although some substantial research has been done on the negative consequences of television ads across the world, the distorting of values caused by exposure to them is an unexplored area. Many researchers have not come across much research on this issue in India. Through this study attempt has been made to evaluate the value implications of inappropriate advertisements being aired on television.

Objectives of the study:

Although, there exists no consensus about the impact of television ads on the value system of viewers, the accusations that we come across in previous research are grave. This study is an attempt to examine the same in the city of Bangalore, Karnataka. Furthermore, this study is an attempt to understand the set of values or beliefs the viewer might draw when contemplating the ethics of controversial practices in television ads.

Methodology and Data Collection:

Questionnaire Development: 
A questionnaire was developed that had statements on the potentially troublesome impact that television ads have on value system practices by youth. The responses to the statements were anchored on a five point scale [likert Scale]. The questionnaire also included respondent profile questions.

\section{Sampling and sample size.}

The study was conducted in the city of Bangalore in Karnataka. The sampling technique used was convenience sampling.

A total of 100 questionnaires were administered out of which 50 were male respondents and 50 female respondents.

\section{Methodology used}

The data collected through questionnaire was further related to a factor and hypothesis pertaining to the factor was established and tested for ANOVA.

\section{Hypothesis}

$\mathrm{H}_{0}$ : There is no significant impact of television advertisements in undermining value system.

$\mathrm{H}_{\mathrm{A}}$ : There is significant impact of television advertisements in undermining value system

ANOVA Table

\begin{tabular}{|l|l|l|l|l|}
\hline Source of variation & Sum of squares & Df & Mean Squares & $\mathrm{F}$ \\
\hline Between samples & 485.86 & 6 & 80.98 & $\mathrm{~F}_{\mathrm{cal}}=2.59$ \\
\hline Within samples & 218.5 & 7 & 31.21 & $\mathrm{~F}_{\mathrm{tab}}=3.87$ \\
\hline
\end{tabular}

$\mathrm{V}_{1}=6, \mathrm{~V}_{2}=7, \square=5 \%$

$\mathrm{F}_{\text {cal }} \leqslant \mathrm{F}_{\text {tab }}$

$2.59<3.87$

Therefore Null hypothesis is accepted.

\section{CONCLUSION}

From the above study we can conclude that television advertisements do not undermine the value system of urban youth.

\section{REFERENCES}

[1] Browne, B.A (1998), Gender stereotypes in advertising on children's television in the 1990s; a cross-national analysis Journal of Advertising, 27 (4), 9-46.

[2] Chan, K, and Cia, X (2009), Influence of television advertising on adolescents in China an urban-rural comparison Young Consumers, 10 (2) $133-145$

[3] Chatterji S. A (2001) How advertisements exploit women (online) Available http://www.gather.com/viewArticle.jsp?articleld=281474976719311 (July 18, 2006)

[4] Childs, N.M and Maher, J.K (2003) Gender in food advertising to children boys eat first British Food Journal, 105 (7), 408-419. Ciochetto, L. (2004). Advertising and globalization in India (online) Available: http://termpapers.org 1123456bc/89 (July 11, 2006), Cleland, G; Koss, D and Muoio (2002) Ethics of weight-loss advertisements (online) Available http://www.ethicsscoreboard.com 1234/a/45 (July 11, 2006)

[5] Drumwright, M.E and Murphy, P.E (2009). The current state of advertising ethics Journal and Advertising ethics Journal and Advertising, $38(1), 83-107$

[6] Fay, M. and Price, C. (1994) Female body-shape in print advertisements and the increase in anorexiz nervosa European Journal of Marketing, 28 (12), 5-18

[7] Ford, J.B., La Tour, M.S. and Honeycutt, E.D (1997) An examination of the cross-cultural female response to offensive sex role portrayals in advertising International Marketing Review, 14 (6), 40-423

[8] Graves, S.B (1999) Television and prejudice reduction when does television as a vicarious experience make a difference? Journal of Social Issues, 55, 707-727.

[9] Haefner, M.J. (1991), Ethical problems of advertising to children Journal of Mass Media Ethics, 6, 83-92.

[10] Henthrone, T.L and LaTour, M.S (1994) Ethical judgements of sexual appeals in print advertising. Journal of Advertising, $2327-29$.

[11] Kunkel, D (1998) The evolution of children's television regulatory policy . Journal of Broadcasting and Electronis Media, 31(Fall), 267389

[12] Kunkel, D (1992) Children's television advertising in the multichannel environment. Journal of communication, 42 (3), $134-152$.

[13] Malhotra, N.K (2007), Fundamentals of Marketing Research. Sage publications, 586-607

[14] Nuta, C. (2009). Does advertising promote excessive consumerism? (online) Available: (May 25, 2010)

[15] Pollay, R (198) The distorted morror: reflections on the unintended consequesnces of advertising. Journal of Marketing, 50(April), 18-36

[16] Richins M.L (1991). Social comparison and the idealized images of advertising. Journal of Consumer Research, 18(1), 71-83

[17] Richins M.L (1995). Social comparison, advertising and consumer discontent. American Behavioral Scientist, 38(4), 593-607

[18] Roy,S.K (2006) Advertising and consumer discontent(online). Available: http://www.icfaipress.org/906.AE.asp (October 11, 2006) 
[19] Saffer, H and Dave, D (2003) Alcohol advertising and alcohol consumption by adolescents. Working paper No. 9676, National Bureau of Economic Research, Cambridge. 